\title{
GPA33 wt Allele
}

National Cancer Institute

\section{Source}

National Cancer Institute. GPA33 wt Allele. NCI Thesaurus. Code C51027.

Human GPA33 wild-type allele is located in the vicinity of $1 \mathrm{q} 24.1$ and is approximately 38 $\mathrm{kb}$ in leng th. This allele, which encodes cell surface A33 antigen protein, plays a role in cell adhesion or may be involved in cell surface receptor regulation; however these roles have not been substantiated. 